the alveoli and gums is present, because in the purulent material that is produced they find a very congenial soil and they thus acquire a certain virulence. In the next place they enter the tissues at points where the local reaction is insufficient to hinder them from migrating into the nearest lymphatic glands, or into the blood, where they cause a general infection. It would be of great scientific interest to test this hypothesis by experiments on animals.

3. In both cases Marmorek's serum was used and it appeared to be without influence upon the course of the infection.

Bologna.

\section{ELECTRIC SHOCKS AT 500 VOLTS.}

BY ALEXANDER PELHAM TROTTER, MEMBER OF THE INSTITUTION OF ELECTRICAL ENGIYEERS.

A GOOD deal of misapprehension exists as to the circumstances under which shocks at 500 volts may be felt or the conditions which may lead to serious consequences. The electric pressure of 500 volts has become well established as the standard for electric traction, but apparatus designed for this pressure can be arranged to take another 100 or 150 volts without appreciable alteration. Conditions of commercial standardisation seem to set the limit for working at about 600 volts ; and it is fortunate, from the point of view of safety, that no further extension of pressure under ordinary conditions is likely to be needed.

Since in a few cases shocks at 500 volts have been fatal newspapers have not hesitated to argue from the particular to the general and have assumed that all such shocks involve serious injury, if not death. For once they are in good company; the technical press and eminent practical electric traction engineers seem to have a horror of 500 volts. Such horror has its wholesome side, but ignorance brought face to face with imaginary horrors may result in panic. Modern journalistic sensationalism has made the most of the accident which occurred in Liverpool in February, 1901, and such was the scare that months afterwards, when a harmless necessary trolley-wire fell on to a tramcar, passengers, not only jumping to the conclusion that they were threatened with a hideous death, jumped to the ground and sustained serious injuries. Irresponsible correspondents have suggested in the newspapers that to fall on the electric rails of the Central London Railway is to be grilled alive; they knew no better. But when during the inspection of the last extension of the City and South London Railway I stood on the rails in wetted boots, and sat on the live conductor and slapped the running rails with my bare hands, engineers, electricians, $r$ tilway employés, and others who ought to know better, were surprised, and they spoiled the effect of my demonstration by suggesting that I was peculiarly insusceptible to shocks. A pressure of 300 volts was used at first for electric traction, but when afterwards it was taken up and developed by Americans they settled by experimenta in corporibus vilibus that a pressure of 500 volts was high enough for economy and not too high for safety.

The chief object of this paper is to record a few experiments and to discuss the conditions under which shocks at 500 volts are devoid of danger. The subject may be divided into three parts : (1) the physiological and electrical conditions; (2) the dangers connected with trolley-wires; and (3) the dangers of third rails of electric railways.

Physiological and electrical conditions. - In dealing with the first part I need but barely allude to physiological matters, but I will refer first to the current, then to resistances, and lastly to pressure. The sensation may be a prick, a pleasant tingle, a hot burning, or a convulsive shock. The sensation does not depend directly on the actual current but on the current density. With four or five square inches (30 square centimetres) of contact between dry metal and bare skin (for example, grasping a trolley-wire) a steady continuous current of one or two milliampères is hardly perceptible. $^{2}$ From 3 to 8 are easily supportable, above 10

I A paper read before the Institution of Electrical Engineers on Feb. $27 \mathrm{th}, 1902$

I If this paper be read, as I hope it may, by others than electricians it may be well to explain that one amperre of eurrent passes through a milliampères is painful, and above 35 almost unendurable. A larger current than 20 milliampères in seldom used for medical applications. Every electrical engineer is familiar with the sharp pricking shock given by a fine wire. In that case the current density is very high, but the current is so small that little else than the tactile nerve-endings in the skin are stimulated. With larger currents and more surface muscular contractions are added to the tactile sensations, especially if the current is at all unsteady. The electrical phenomena of nerve and muscle have been studied by physiologists; they are rather complicated and do not concern the general purpose of this paper. Alternating currents seem to be about four or five times more painful, but the sensation is of a different character. I have no knowledge of the relative danger of alternating and of continuous currents, and no further reference will be made to alternating currents in this paper. It is difficult to make any exact determination of the relation between current density and sensation. More than about 14 milliampères of steady continuous current at the finger-tip, making a poor contact of about one-sixth of a square inch (one square centimetre), is unendurable, but 35 milliampères from boot to boot, nearly the whole of the soles of the feet being in contact, is much less painful. Under prolonged shock the current increases owing to a fall of resistance, but that does not concern accidental shocks.

Passing now to resistances, the resistance from finger-tip to finger-tip on dry metal and under 100 volts is about 20,000 ohms. It varies a little with the volts, decreasing at higher pressures. Two coins nipped in the terminals of an Evershed ohmmeter serve very well for electrodes. This finger-tip resistance is of considerable importance in connexion with accidental light contacts at high pressures. The resistance is almost all at the skin. The thin skin on the inside of the wrist is much more sensitive than that of the palm of the hand. The difference between the resistance from finger to finger of one hand and between one finger of each hand is inappreciable. The resistance from hand to hand when grasping two pieces of dry trolley wire is about $5000 \mathrm{ohms}$; different individuals vary a good deal, probably owing to the dryness of the skin; I have found it as high as 14,000. The resistance between the body and the earth or an iron rail through the sole of the foot, stocking, and boot, is of considerable importance in connexion with electric railways. I find that the resistance from boot to boot, the boots being dry and without nails, varies from 45,000 to more than $200,000 \mathrm{ohms}$. The lowest of measurements on 25 different persons made with 500 volts gave 25,000 ohms. Boots worn into holes and wetted by walking on wet pavement gave only 13,000. The values for resistance of the human body given in medical works are of little use for the present purpose, for care is taken as a rule to facilitate the passage of the current. "Under conditions of medical practice, and using moistened electrodes, the resistance of the body, when the skin is well wetted with warm water, is about 2000 or 3000 ohmsthat is to say, an electromotive force of 12 volts (eight Leclanché cells) will pass a current of four to six milliampères." 3 Most of the measurements of resistance which $I$ have given were made with from 100 to 500 volts and are calculated from the milliampères which passed. Taking the information which I have already given about the effect produced by various currents it follows that the mere touching of dry metal at 100 volts, finger to finger, gives hardly any sensation, but with a larger contact a shock is felt. At 200 volts a light touch gives an unpleasant prick, but the current through a firm contact is about from 12 to 18 milliampères, which most people can bear without considerable pain, especially if the contact be gradually made and broken. There is no after effect; the sensation is very similar to that of heat. To grasp with bare hands two pieces of metal at 500 volts would give a very painful shock, but a light and quick touch is no worse than the shock from a half-pint Leyden jar, an experience more familiar to schoolboys than to

milliampère, or one thousandth of an ampère, passes through a resistance of $1000 \mathrm{ohms}$ when the pressure is one volt, and one milliampere passes when the resistance is 100,000 ohms and the pressure 100 volts, and so on in proportion.

\begin{tabular}{ccccccrrrrrr} 
Volts. & \multicolumn{1}{c}{ Milliampères. } & \multicolumn{1}{c}{} & & Ohms. \\
1 & $\ldots$ & $\ldots$ & $\ldots$ & $\ldots$ & $\ldots$ & 1,000 & $\ldots$ & $\ldots$ & $\ldots$ & $\ldots$ & 1 \\
1 & $\ldots$ & $\ldots$ & $\ldots$ & $\ldots$ & $\ldots$ & 1 & $\ldots$ & $\ldots$ & $\ldots$ & $\ldots$ & 1,000 \\
100 & $\ldots$ & $\ldots$ & $\ldots$ & $\ldots$ & $\ldots$ & 1 & $\ldots$ & $\ldots$ & $\ldots$ & $\ldots$ & 100,000 \\
500 & $\ldots$ & $\ldots$ & $\ldots$ & $\ldots$ & $\ldots$ & 5 & $\ldots$ & $\ldots$ & $\ldots$ & $\ldots$ & 100,000
\end{tabular}

3 Lewis Jones: Medical Electricity, p. 194.
Ohms.

1,000

100,000 
engineers. A 500-volt shock may be described as worse than touching a kettle of boiling water, not so bad as touching a red-hot poker, about the same as touching a soldering iron at working heat, or as when an inexperienced blacksmith's boy picks up a black-hot horseshoe. These shocks are common incidents in the daily work of a careless linesman; nearly all those who are practically engaged in electric traction work receive more shocks than they like, but they agree that they might reduce the number by taking more care. This is an important measure of the severity of such shocks, and perhaps the only one which will be appreciated by those members of the public who do not care to try for themselves. In such brief shocks the muscular sensations probably mask the contact sensations, but a bad 500-volt shock burns the skin.

Cases of fatal accident from 500 volts are so rare that the conditions can only be guessed at. If the skin resistance be reduced by moisture, especially if salt or chemicals be present, and if the contact be large and prolonged, 100 volts may be fatal. While repairing an arc lamp in a steam washing factory at Bradford in 1899 a man is said to have been killed by a shock at 225 volts ; a fatal accident occurred in Germany with about 300 volts ; but a man may be choked by a crust of bread under exceptional conditions. The death of a man by blood-poisoning arising from a burn caused by a short circuit on the Central London Railway in December, 1900, does not concern us; a death occurred on the Metropolitan Railway in Paris, when a platelayer fell and remained fallen on the third rail of 500 volts. But the case to which so much attention has been drawn and which has caused such a scare is the accident in Pembroke-place, Liverpool. Instead of the present system of well-earthed guard.wires an attempt was made to keep fallen telegraph wires from touching the trolley wire, and the attempt was unsuccessful. Nearly 50 wires fell in a tangle across the street and lay on the trolley wire, which did not break. The passers-by in the street upon whom they fell escaped with a few shocks. It was dark and snowing and a salted slush lay on the street. Two men walked blindly into the wires and were entangled, and, struggling, became entangled the more. 'The current was not cut off' for nearly half-anhour. Here was a lamentable combination of seven circum. stances: (1) the unusual conditions of weather, the snow freezing to the wires as it fell; (2) failure of the wood strip (which is still extensively used on the continent) to act as a guard; (3) the large number of wires, the long span ( 375 feet), and the tangle in which they fell; (4) the salt slush of snow in the street; (5) the darkness and invisibility of the wires; (6) failure of the police telephone signal service; and (7) the delay of 25 or 30 minutes before the current was cut off. If anyone of these seven causes had been absent it is probable that the fatal results would not have occurred. It is practically impossible that such ari accident can occur again in Liverpool, for the telephone wires which crossed the tramways have been either diverted, placed underground, or cabled, at a great expense to the corporation. and a considerable number of the postal telegraph wires have been satisfactorily altered. I am tempted to digress into the question of guard-wiring, but this paper must be confined to shocks, and I hope that the discussion will be similarly restricted.

Dangers connected with trolley wires.-Neither the man in the street nor a man on a car runs any risk of taking 500 volts skin to metal. On several occasions during inspections of tramways when a trolley wire has been within reach from the top of a car 1 have grasped it with both hands, and with more or less difficulty I have persuaded others to do the same. In each case the weather was fine, the car was dry, and no shock, not even the least sensation, was perceptible. To show that there was no trick I have grasped the hand-rail and flicked the trolley wire with a finger ; the shock is trifling. It follows, therefore, that if a live trolley wire fall on a crowded car, although it may give alarming flashes when it touches a hand-rail or tramway rail, the chances of a shock on a fairly dry day are nothing compared to the obvious mechanical injuries which might be occasioned. Trolley wires do fall and trolley wires are very properly excluded from the leading cities of the world-London, Paris, Vienna, New York, Budapest \&c. - but as yet the damage done by the falls has not been electrical. A trolley-wire is an obvious thing; it sometimes springs back in large coils, but it generally falis and lies still or hangs, and it is regarded with a prudent solicitude which this paper is not intended to remove. But on a dry or frosty day anyone with tolerably good boots may fearlessly touch the live end even if he stand on the rail. I would not publish this statement had I not tried the experiment on some dozen persons, the majority being women and children. My son, seven and a half years old, stood on a rall and played with wires, there being 500 volts between rail and wires. The current was less than one-quarter of a milliampère and he felt nothing. His boots were new. A fallen telephone wire is not so obvious It does not stop the traffic ; it is apt to writhe and to coil round a person; should he fall on the rails the short circuit might severely burn him. With wet boots and wet ground the conditions are different. Standing on damp granite setts in rather damp boots, and orasping a trolley-wire, I found that the current was 15 milliampères. The sensation was by no means unendurable; brief touches gave sharp pricks. Standing on a rail increased the current to 20 milliampères. With old boots worn into holes, and after walking a couple of miles on wet pavement, standing on a rail and grasping a trolley-wire gave 35 milliampères. I took this for several seconds, and $I$ should be sorry to take more. I broke contact cautiously by raising the boot on one edge. There was no after effect; the sensation was merely that of heat, as though the trolley-wire were hot. Spilling half a bucketful of water on the ground increased the shock intolerably. I am inclined to attribute this to the better contact between boot and earth rather than to decreased resistance of the earth (in this case granite setts). Three others tried the experiments with me, and as far as we are able to compare experiences I am satisfied that $I$ am not relatively insusceptible to shocks.

Besides the fall of trolley-wires, either on a car or in the street, there are roundabout and unlikely ways in which shocks may be conveyed to unsuspecting persons; for example, a linesman on a ladder, and somehow making a good earth, holding a wire while its broken end or a careless sag touches a trolley-wire; but the discussion of such accidents belongs to the subject of guard-wires.

Dangers of third rails of electric railways - The first time that $I$ stepped on the live rail of a third-rail railway $I$ clutched the engineer lest my legs should give way under the shock, but I felt nothing. I went to where some water stood half an inch deep on a cement floor and "marked time" for two and a half minutes. With caution I stepped on to the live rail and then on to one of the running rails, felt nothing and then stooped down and touched the running rail while standing with both feet on the running rail. I felt a slight tingle, which my subsequent experiments lead me to think was produced by a current of about six milliampères. To sit on the live rail without touching the running rails was easy, and I cautiously flicked the running rail, then touched it, and then laid my hands flat on it without the slightest sensation. In the light of the figures which have given this is not at all surprising, and $I$ have invited several others to try the experiment, with the same negative result. Of course, the result depends on the dryness of the clothes. The resistance of dry cloth is very high. After walking in the wet for about an hour with sound but not thick shoes I stepped on 500 volt rails and felt nothing, but on touching with the finger I received a smart shock, perhaps 30 milliamperes. I have already stated that with old worn. out and wet boots the resistance was only $13,000 \mathrm{ohms}$. This was found with only 400 volts. Standing on rails in my laboratory. the rails being connected to the outers of the Westminster Company, I could just support the current of about 30 milliampères. The sensation was almost precisely like that of standing on hot steam-pipes. It was easy to turn it on gradually by beginning and ending with the edge of the sole. The shock would, of course, be very alarming to anyone who was not expecting it. There was no perceptible after-effect. Ordinary nails in the heels of boots make no difference, but hob-nails give uncertain pricking stings which are rather painful, but under no circumstances need they be sustained. Until I tried these experiments I must confess that I did not enjoy the walks which I have sometimes taken in "tube" railways during inspections by the light of oil lanterns, but now, with dry boots, I take no care whatever. It is very desirable that the live rails of third-rail railways should be guarded by planks to prevent short circuits by tools, \&c., and to make it less easy for a person falling on the rails to make contact with bare skin. While experience has shown that a person so falling may receive a serious and even fatal shock, this can only occur if he make contact with both a live rail and a running rail with bare skin, or thoroughly wetted 
clothes, and if he lie there for a time. As to the length of this time we know nothing, but so long as the fall has not injured the person so that he cannot rise it is very improbable that the shock would be maintained. A platelayer in the open-yard of the Waterloo and City Railway once accidentally sat on the third rail and made the circuit through his feet on wet ground; he shouted and was pulled off by his mates; the contraction of the muscles prevented him from rising. He could probably have rolled over and so released himself. He was back at work again in a few minutes.

Numerous accidents to horses show conclusively that these animals are peculiarly susceptible to electric shocks. Electrical conditions under which a human being would receive an unpleasant shock of from 10 to 15 milliampères cause instant death to a horse, and it appears that horses are terrified under conditions where a human being would feel no shock. But it must not be concluded that a given current produces more effect on a horse than on a man. A horse makes excellent contact with its shoes, and these are well connected by nails to its body. It is probable that the resistance is very small and the current very large; but even making this allowance the horse appears to be more susceptible.

Conclusion.-The dangers of electric shocks at 500 volts have been much misunderstood, greatly exaggerated, and little investigated. The pressure of 500 volts has been deliberately chosen by electrical engineers because it is not dangerous under ordinary conditions. The conditions under which serious shocks are not produced by 500 volts are discussed in the paper, and it is safe to assume that all shosks more serious than those which are recorded are dangerous. Dry wood and dry boots without large nails offer so great resistance to electric current that it is perfectly safe to touch a trolley-wire whlle standing on a dry tram-car, or even while standing on the ground or on the rails. Wet weather makes a considerable difference, but boots must be very wet to allow enough current to pass to produce a severe shock. Men engaged in electric traction work receive many slight electric shocks at 500 volts, and they might avoid most of them by taking more care. Dry clothing offers so great a resistance that no shock can be transmitted through it. The peculiar conditions under which shocks at 500 volts have caused death are discussed and are shown to be very exceptional. Experiments have been made on some 30 persons, including 12 women and six children, and it is proposed to make other experiments. With sound dry boots hardly anybody can feel a shock when standing on the live rail of an electric railway with one foot and a running rail with the other. With damp or wet boots a shock is felt, but neither the sensation nor the degree of wetness of the boots can be measured accurately. It is not possible to receive a shock by sitting or lying on a live rail so long as the clothes are dry and continuous-that is to say, so long as the live metal is not touched by the bare skin.

\section{A CRITICISM ON THE VISUAL TEST AS USED IN THE BRITISH ARMY.}

\section{BY A. A. BRADBURNE, L.R.C.P. \& S. EDIN., L.F.P.S. GLASG.,}

CIVIL SURGEON TO THE CONNAUGHT HOSPITAL, ALDERSHOT.

SEEING the importance which is attached to good shooting under the altered conditions of modern long-range rifle-fire it becomes an important question whether the standard of vision at present in vogue is a sufficiently high one. Let us then examine the means adopted for fixing a standard and endeavour to see in what respect it fails.

The visual power of the recruit is tested by means of Professor Longmore's "test dots," which consist of black dots one-fifth of an inch in diameter on a white background, so that by means of a covering card many variations in the number and position of the dots can be obtained. This is held up at a distance of 10 feet from the recruit who is asked to count the number of dots exposed. The black dots as seen at 10 feet are supposed to bear the same relation to a bull's-eye three feet in diameter as seen at 600 yards. The 10 feet being a convenient distance was first taken and then the proportionate size of the black dot found by a process of simple calculation-viz. : as 600 yards : three feet : 10 feet one fifth of an inch.

Now let us see what relation this standard of vision bears. to normal vision-in other words, what amount of bad sight does it allow a recruit to have in the service. According to Volkmann, the minimum visual angle at which an object can: be clearly discerned is one of one minute, and the distance at which such ought to be seen can be easily calculated. when we know the size of the object. The size of each dot. is one-fifth of an inch, and therefore with a normal acuteness of vision each dot ought to be seen at a distance of 57 feet ; but the distance required by the regulations is only 10 feet, or, roughly speaking, a fifth of what good vision ought to consist of. If the other medical requirements were taken on a similar bacis the standard of health and strength would be of a very low order. This lowness of requisite visual ability is even further reduced by the fact that for militia, volunteers, and departmental corps the dots need only be held five feet away.

Such a seemingly low standard would, one might think, admit into the service men with most inferior vision, without the additional opportunities which such a rough-andready method presents for "scraping through." A few statistics taken from notes of over 1000 cases seen by me whilst stationed in Aldershot may show what types do pass the test, the percentages due to "scraping through" being ignored on account of the obvious difficulty of discriminating between them. The state of the refraction was in all cases done under a mydriatic and the following is a fairly accurate summary. Out of every 100, 82 were found to be hypermetropic and 18 to be myopic. Of the hypermetropes 16 per cent. were found to be over $5 \mathrm{D}$. and below $10 \mathrm{D}$. No case of over $11 \mathrm{D}$. was met with. Of the myopes $2 \frac{1}{2}$ per cent. were over $5 \mathrm{D}$. and under $10 \mathrm{D}$., and 1 per cent. were over $10 \mathrm{D}$. and under $15 \mathrm{D}$ No case of over $15 \mathrm{D}$. was met with. of mixed astigmatism the proportion was 4 per cent., and of antimetropia the proportion was $2 \frac{1}{2}$ per cent. Thus we see that, roughly speaking, 25 per cent. of the men who complained of inability to see to shoot were justified in their complaints and had been admitted into the service by either too lax a test or by fraud. The proportion is, of course, misleading unless one bears in mind that the cases examined were only those who had made some complaint about their vi-ion, but that such errors of refraction can pass the test dot is plainly shown.

This leads us to ask, In what particular respect does the test dot fail ? Turning to our figures again we note that it fails to detect first of all fairly high degrees of hypermetropia, secondly mixed astigmatism, and lastly cases of antimetropia and myopia of a degree above $5 \mathrm{D}$. For practical purposes all cases of myopia of $5 \mathrm{D}$. or more can be considered as having passed by "unfair or hurried tests." It is different though, in cases of mixed, compound, or simple astigmatism, as unless the degree be very marked but little difficulty is experienced in counting fairly correctly the exposed dots if not too many be shown and it be done in a good light. Again, in cases of high degrees of hypermetropia it signally fails because at the age (18 years) at which the recruit is generally examined nearly all the hypermetropia is latent. It is in this respect alone that for practical purposes the dots chiefly fail. For example, take a recruit with hypermetropia of $8 \mathrm{D}$, , aged 18 years; his accommodation at this age is $10 \mathrm{D}$, so it is all latent, but test him again in a few years, or at the end of a long march, when bis ciliary muscle is weakened, and the hypermetropia becomes manifest, and the result will be very different.

How are we to remedy this? If we move the dots further away he will still be able to read them, and we would be excluding myopes of a low degree of about $2 \mathrm{D}$. who are of even more use. If we bring the dots nearer we admit myopes of a too high degree and may even then admit cases of hypermetropia of over $5 \mathrm{D}$., which is too high to be of value. If we adopt the plan of finding out the smallest reading type which can be clearly defined we should then exclude the patient with high degrees of latent hypermetropia and in conjunction with the test dots exclude the high myope who could easily pass the reading test. The test dot fails also to diagnose absence of binocular vision, which is shown by the admittance of men with alternating strabismus; but if the recruiting officer were to examine the external appearance of the eyes such would not happen, and, moreover, failure to detect corneal opacities and similar visual defects would not be so often passed over as is so commonly done.

What, then, are the advantages possessed by the test dots 